\title{
Missions in the Southern Caribbean
}

\section{Book Title:}

Ontwikkeling van de zending in het Zuid-Caraïbisch gebied, in het bijzonder onder de Hindostanen 1850-1980

\section{Book Cover}

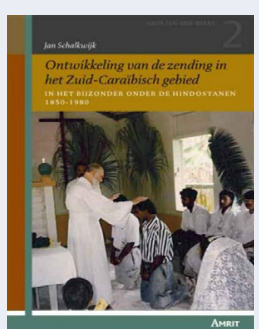

Author:

Jan Schalkwijk

ISBN:

978-90-74897-61-7

Publisher:

Amrit, Den Haag, 2011, 704

p., €25.0*

*Book price at time of review

$\longrightarrow$

Review Title:

Missions in the Southern

Caribbean

Reviewer:

Frank Jabini ${ }^{1}$

\section{Affiliation:}

${ }^{1}$ Postgraduate School, South African Theological Seminary, South Africa

Email:

frankjabini@gmail.com

Postal address:

Postbus 4065, Annaweg 38,

Paramaribo, Suriname,

South America

How to cite this book review: Jabini, F., 2013, 'Missions in the Southern Caribbean', Verbum et Ecclesia 34(1), Art. \#795, 1 page. http://dx.doi. org/10.4102/ve.v34i1.795

\section{Copyright:}

(C) 2013. The Authors. Licensee: AOSIS OpenJournals. This work is licensed under the Creative Commons Attribution License.

Read online:

$\begin{array}{ll}\text { Read online: } & \text { scan this QR } \\ \text { code with your } & \text { smart phone or } \\ \text { mobile device } & \text { to read online. }\end{array}$

Jan Schalkwijk served the Moravian Church in Suriname from 1952 to 1970 . From 1974 to 1978 he served at United Theological College of the West Indies in Jamaica as an ecclesiastical professor. Schalkwijk started his research for a doctoral dissertation on missions amongst the (East) Indians of the Southern Caribbean in 1971 and continued after he returned to the Netherlands from Jamaica in 1978. Professor Johannes Verkuyl was his promoter and Dr Jan van der Linde his copromoter. In 1984, when Verkuyl retired, the Vrije Universiteit of Amsterdam assigned Schalkwijk a new promoter. At that time the dissertation was complete. The new promoter, however, was of the opinion that the dissertation was too lengthy. He therefore advised Schalkwijk to limit the research to Suriname and to add a few pages on the two other countries in the Southern Caribbean, Trinidad and Guyana. Schalkwijk never completed this task. He passed away in 2004. His son, Professor Marten Schalkwijk, and others prepared the dissertation for publication.

The work has three major parts. The first part (pp. 21-216) consists of four chapters. In these chapters he describes the Southern Caribbean missions context (ch. 1), Caribbean missions (ch. 2), churches of the Southern Caribbean (ch. 3) and churches of the common people and the minorities (ch. 4). The second part (pp. 217-504), also consisting of four chapters, is the main part of the dissertation. It presents a detailed study of missions amongst the Indians in Trinidad (ch. 5), Guyana (ch. 6) and Suriname (ch. 7). Each chapter is divided into four main parts, based on the developments in each country. Chapter 8 centres on the inter-Caribbean Indian missions (Grenada, St. Lucia and Jamaica) and collaboration amongst churches and missionaries. The third part studies the North Atlantic continuation of missions to Indians (ch. 9) and gives conclusions and perspectives (ch. 10). An epilogue and a massive bibliography complete the work.

Indians arrived in the Caribbean as indentured labourers after the abolition of slavery. They arrived in Guyana and Trinidad in 1845 and in Suriname in 1873 (p. 36). More than 80\% of these migrants were Hindus and the rest were Muslims or Christians (p. 37). Most migrants remained in the Caribbean after their contracts expired. Their descendants are a very prominent group in the Southern Caribbean. Leaders from amongst them have been elected to the presidency in all three countries. In 1970, Indians formed $43.7 \%$ of the population of the Southern Caribbean (p. 26).

Christian missions amongst them started very early after their arrival. Three groups have been involved: churches that were already in the Caribbean when they arrived (pp. 218-219), churches from North America (pp. 219-221) and Indians who were Christians in India before they migrated to the Caribbean (pp. 221-224). The early work in Trinidad and Guyana was dominated by the Presbyterians. The Moravians and the Roman Catholics were the main players in Suriname. In the 20th century new churches entered the arena and worked amongst the Indians as well. Schalkwijk gave attention to both male and female missionaries, expatriates and local workers. He described the various aspects of the missionary endeavour in these countries. Missionary work was conducted along ethnic lines, hence the use of the term 'Indian missions'. The work is a history of missions amongst the Indians in the Caribbean with a theological interpretation.

What is the result of more than a hundred years of missions amongst the Indians in the Southern Caribbean? Schalkwijk gave the following statistics for the percentage of Christians in 1970:

- Central North India $0.1 \%$

- Suriname 5\%

- Guyana $11 \%$

- Trinidad 25\% (pp. 371-372).

There has not been a significant change in these numbers since Schalkwijk concluded his research.

This is the first work to conduct such a detailed missiological study on the Indians in the Caribbean. By studying more than one country, he was able to do comparative studies. The similarities between the countries of the Southern Caribbean lend themself well to such a task. An English translation of this work will serve students of missions in the Caribbean very well. 